\title{
Rancangan Prototype Layanan Pengaduan Masyarakat Melalui Kantor Desa Berbasis Android
}

\author{
Yurindra $^{[1]}$, Sarwindah $^{[2]}$, Devi irawan ${ }^{[3]}$ * \\ Teknik Informatika ${ }^{[1],[3]}$, Bisnis Digital $^{[2]}$ \\ Institut Sains dan Bisnis Atma Luhur \\ Pangkalpinang, Bangka Belitung \\ yurindra@atmaluhur.ac.id ${ }^{[1]}$,indah_syifa@atmaluhur.ac.id ${ }^{[2]}$, deviirawan@atmaluhur.ac.id ${ }^{[3]}$
}

\begin{abstract}
Abstrak - Salah satu Peningkatan kualitas pelayanan public bagi masyarakat pedesaan adalah dapat dengan dilakukan melalui sebuah penyelesaian pengaduan yang mendapatkan respon yang cepat dari penyedia layanan yaitu dalam hal ini instansi pemerintah terkait baik di pusat maupun daerah. Segala bentuk kritik, saran maupun aduan yang disampaikan masyarakat pada suatu instansi merupakan sebuah koreksi untuk perbaikan pelayanan tersebut. Banyak Kantor Desa di Indonesia belum memiliki sistem layanan pengaduan yang teridentifikasi dan terdokumentasi dengan baik, sehingga timbul kendala dalam memberikan layanan pengaduan kepada masyarakat, seperti respon time pelayanan yang lambat dan dokumentasi pengaduan tidak tertata dengan rapi. Kendala lain timbul saat masyarakat kebingungan untuk menyampaikan keluhan tersebut dikarenakan tidak mengetahui harus mengadu kemana. Untuk mengatasi masalah tersebut, akan dirancang aplikasi layanan pengaduan berbasis Android yang menggunakan model prototype dan menggunakan MySql sebagai database pada server yang digunakan. Dengan itu diharapkan agar dapat memudahkan masyarakat dalam membuat laporan pengaduan. Aplikasi Android ini dapat digunakan masyarakat untuk melakukan layanan pengaduan secara online. Aplikasi ini juga dapat memudahkan Pemerintah desa dan kabupaten dalam melakukan dokumentasi dan mengevaluasi sistem layanan pengaduan masyarakat desa.
\end{abstract}

Kata Kunci: layanan pengaduan, Pengaduan online, Layanan desa, Pengaduan berbasis android.

Abstract - One way to improve the quality of public services for rural communities is to do it through a complaint settlement that gets a fast response from service providers, namely in this case the relevant government agencies both at the center and the regions. All forms of criticism, suggestions or complaints submitted by the public to an agency are a correction for the improvement of these services. Many Village Offices in Indonesia do not yet have a complaint service system that is identified and well documented, so that problems arise in providing complaint services to the community, such as slow service response times and poor documentation of complaints. Another obstacle arises when people are confused about how to submit their complaints because they do not know where to complain. To overcome this problem, an Android based complaint service application will be designed that uses a prototype model and uses MySql as a database on the server used. It is hoped that this will make it easier for the public to make complaints reports. This Android application can be used by the public to provide online complaints services. This application can also make it easier for village and district governments to document and evaluate the village community complaint service system

Keyword: service complaint, complaint online, service village, complaint based android

\section{PENDAHULUAN}

Undang-Undang Nomor 6 Tahun 2014 tentang Desa dan Peraturan Pemerintahan Nomor 43 Tahun 2014 Peraturan Pelaksanaan Undang-Undang nomor 6 tahun 2014 tentang desa, memberikan kewenangan kepada desa untuk mengatur dan mengurus kepentingan masyarakat setempat. Selanjutnya di dalam ketentuan umum di sebutkan bahwa Desa adalah kesatuan masyarakat hukum yang memiliki masyarakat wilayah yang berwenang untuk mengatur dan mengurus urusan pemerintahannya sendiri, kepentingan masyarakat, hak asal usul, dan/atau hak tradisional yang di akui dan dihormati dalam system pemerintahan Negara Kesatuan Republik Indonesia agar mampu membrikan komukasi dua arah yang baik[11].

Kepulauan Bangka belitung terdiri dari 1 kotamadya, 6 kabupaten, 47 Kecamatan dan 82 Kelurahan yang tersebar di seluruh Bangka belitung. Khusus desa ,kabupaten dan kotamadya sesuai dengan data Biro pemerintahan Kepulauan Bangka belitung pada survey terakhir tahun 2006 adalah memiliki desa seperti pada tabel dibawah ini :

Tabel 1. Jumlah Desa Kepulauan Bangka Belitung

\begin{tabular}{|l|c|l|} 
Kabupaten/Kota & \multirow{2}{*}{ Jumlah desa } & \multicolumn{1}{c|}{$\begin{array}{c}\text { App } \\
\text { Pengaduan }\end{array}$} \\
\hline Bangka & 62 & tidak ada \\
\hline Belitung & 42 & tidak ada \\
\hline Bangka Barat & 60 & tidak ada \\
\hline Bangka Tengah & 56 & tidak ada \\
\hline Bangka Selatan & 50 & tidak ada \\
\hline Belitung Timur & 39 & tidak ada \\
\hline Pangkal Pinang & 0 & tidak ada \\
\hline \multicolumn{1}{|c|}{ Jumlah } & $\mathbf{3 0 9}$ & \\
\hline
\end{tabular}


Setiap Kantor Desa memliki kendala dalam memberikan layanan pengaduan kepada masyarakat, seperti waktu respon pelayanan yang menjadi kendala bagi kebutuhan masyarakat pedesaan. Masyarakat desa pada umumnya mengadukan permasalahan yang terjadi di lingkungan tempat tinggal, seperti adanya pencurian, perkelahian, kecelakaan , perselisihan dan sengketa tanah . Pada saat ini, proses pengaduan di daerah pedesaan di wilayah Bangka belitung masih dilakukan secara manual. Masyarakat harus melakukan pengaduan dengan cara mengisi formulir didesa, selain itu sistem pengaduan seperti ini sering terjadi masalah yang tidak diinginkan, seperti penulisan kurang jelas dan menyita waktu yang cukup panjang sehingga cukup menyulitkan bagi masyarakat desa. Proses pengaduan seperti ini juga sering tertunda dengan ketidakhadiran perangkat desa yang berwenang saat dibutuhkan untuk membuat laporan pengaduan.

Dapat dilihat pada tabel1 jumlah desa tersebut di atas bahwa di Propinsi Kepulauan Bangka belitung sebagai studi kasus penelitian ini tidak terdata satupun desa yang telah memiliki layanan pengaduan terhadap kejadian-kejadian yang terjadi didesa. Yang tersedia hanya layanan pengaduan terhadap kinerja pemerintah desa seperti ombudsman dan lain sebagainya.

Untuk mengatasi masalah diatas, maka dirancang aplikasi layanan pengaduan berbasis Android untuk digunakan oleh masyarakat pedesaan khususnya. Android dipilih karena populer dan banyak digunakan oleh masyarakat di Wilayah Bangka belitung. Aplikasi Android ini dapat digunakan masyarakat untuk melakukan layanan pengaduan secara online. Sehingga masyarakat yang melakukan pengaduan tidak perlu datang ke Kantor Desa, hanya dengan menggunakan gadget berbasis android masyarakat dapat melakukan pengaduan. Disamping itu aplikasi yang akan dibuat dapat memudahkan instansi dalam mendokumentasi laporan pengaduan masyarakat. Beberapa Penelitian terdahulu menunjukan bahwa pentingnya kanal layanan sejenis untuk dioperasikan, misalnya kanal layanan aduan di perguruan tinggi [1], layanan terhadap layanan publik di pemerintahan[2], pengaduan layanan sejenis di pedesaan [3] ,Analisis terhadap aplikasi "lapor" yang telah di rilis pemerintah untuk kabupaten kota dan propinsi[4] serta aplikasi pengaduan untuk "kecamatan" [5]. Penelitian ini mampu memberikan kontribusi bagi pemerintahan desa dalam melakukan evaluasi terhadap sistem layanan di desa yang menggunakan aplikasi ini nantinya. Tingkat kepuasan pengguna dari pihak masyarakat dan tenaga admin atau operator desa tentu harus diukur pada saat aplikasi ini di implementasikan sehingga mampu untuk dilakukan evaluasi sehingga pada akhirnya akan menjadi bahan kontribusi yang baik untuk desa pengguna aplikasi ini.

\section{METODOLOGI PENELITIAN}

\section{A. Jenis Penelitian}

Jenis penelitian pada pengembangan sistem layanan pengaduan masyarakat desa ini menggunakan jenis penelitian Terapan dengan urutan penelitian berdasarkan Perencanaan,
Analisis, Desain dan Impelementasi ( Software development life cycle), dengan menggunakan bahasa pemrograman android didasarkan pada hasil analisis kebutuhan masyarakat desa serta hasil analisis kebutuhan pemerintah desa terhadap sistem layanan tersebut. Data awal didapatkan dari hasil analisis kuantitatif dari hasil survey ke pengguna dan hasil akhir penelitian ini juga didukung dengan hasil survey berupa data kuantitatif dari pengguna .

\section{B. Metode dan model penelitian}

Metode yang digunakan dalam penelitian ini menggunakan pendekatan berorientasi objek, sedangkan model pengembangan perangkat lunak menggunkan model prototype, sehingga tidak semua fitur dalam rancangan dapat dijalankan dengan sempurna.

\section{Perencanaan}

Desa yang digunakan sebagai pilot project penelitian ini adalah desa Pedindang kabupaten Bangka tengah, dikarenakan dekat dengan lokasi peneliti. Pengumpulan data dilakukan sebanyak dua kali, yaitu pertama saat melakukan analisis kebutuhan perangkat lunak terkait dengan seberapa besar aplikasi ini diharapkan atau dibutuhkan oleh pemerintah desa dan masyarakat ( menggunakan teknik random sampling sebanyak 8 orang perangkat desa dan 32 orang masyarakat desa). Kedua adalah saat prototype perangkat lunak selesai dibuat yaitu untuk mengetahui tanggapan pengguna yaitu perangkat pemerintahan desa dan masyarakat desa ( menggunakan teknik random sampling sebanyak 8 orang perangkat desa dan 32 orang masyarakat desa). tentang kemudahan penggunaan protoype aplikasi yang telah dibuat.

Tabel 2.Questioner kebutuhan masyarakat

\begin{tabular}{|l|l|c|c|c|c|}
\hline NO & Jabatan & \multicolumn{5}{|c|}{ Pernyataan } \\
\hline & & SS & S & TS & STS \\
\hline 1 & Ka.desa & & 1 & & \\
\hline 2 & Sek. Des & & 1 & & \\
\hline 3 & Kasi Pelayanan & & 1 & & \\
\hline 4 & Kasi Pememrintah & & 1 & & \\
\hline 5 & Kasi Kesejahteraan & & 1 & & \\
\hline 6 & KAUR Umum & & 1 & & \\
\hline 7 & KAUR Perencanaan & & 1 & & \\
\hline 8 & KAUR keuangan & & 1 & & \\
\hline 9 & Masyarakat desa & 10 & 20 & 2 & \\
\hline \multicolumn{7}{|c|}{ TOTAL } & $\mathbf{1 0}$ & $\mathbf{2 8}$ & $\mathbf{2}$ & $\mathbf{0}$ \\
\hline
\end{tabular}

Dari tabel2 tersebut dapat di lihat bahwa dari pihak pemerintahan desa menyatakan setuju dengan diperlukannya aplikasi ini bagi kebutuhan masyarakat desa dan pemerintahan desa . Sementara itu dari pihak masyarakat 10 orang menyatakan sangat setuju dengan dibuatnya aplikasi ini, 20 orang menyatakan setuju dan ada 2 orang menyatakan tidak setuju dengan diterapkannya aplikasi ini.

\section{Analisis dan Perancangan Perangkat Lunak}

Analisis kebutuhan berjalan dapat dilihat pada gambar sebagai berikut ini : 


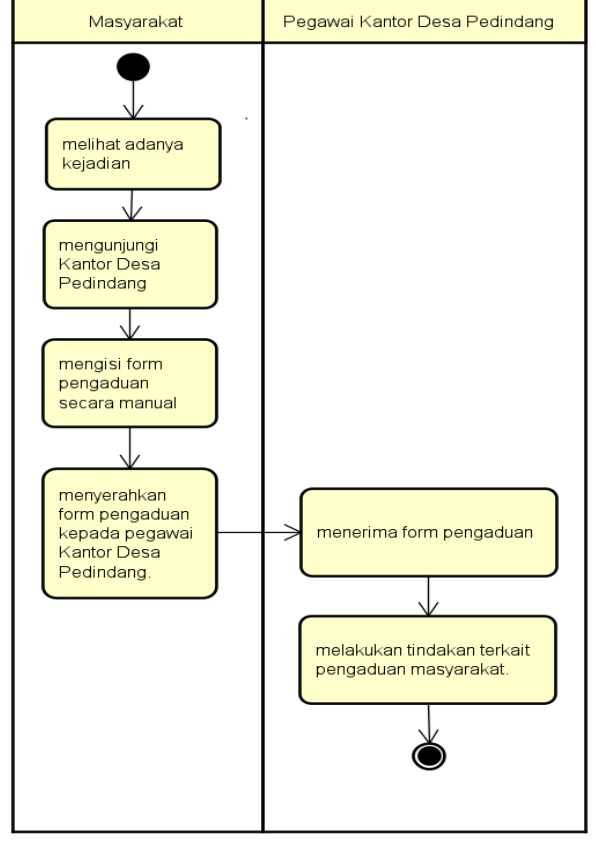

Gambar 1. Analisis sistem berjalan

Dalam gambar tersebut dapat dilihat prosedur pelaporan gangguan dilingkungan yang memakan waktu dan tempat sehingga dirasakan tidak efektif untuk dilakukan. Padahal kesigapan petugas terhadap respon pelaporan publik menjadi tujuan utama pada aplikasi ini seperti pada riset di Polres Enrekang[7],[8].

Rancangan proses layanan pengaduan dapat dilihat pada diagram activity berikut ini :

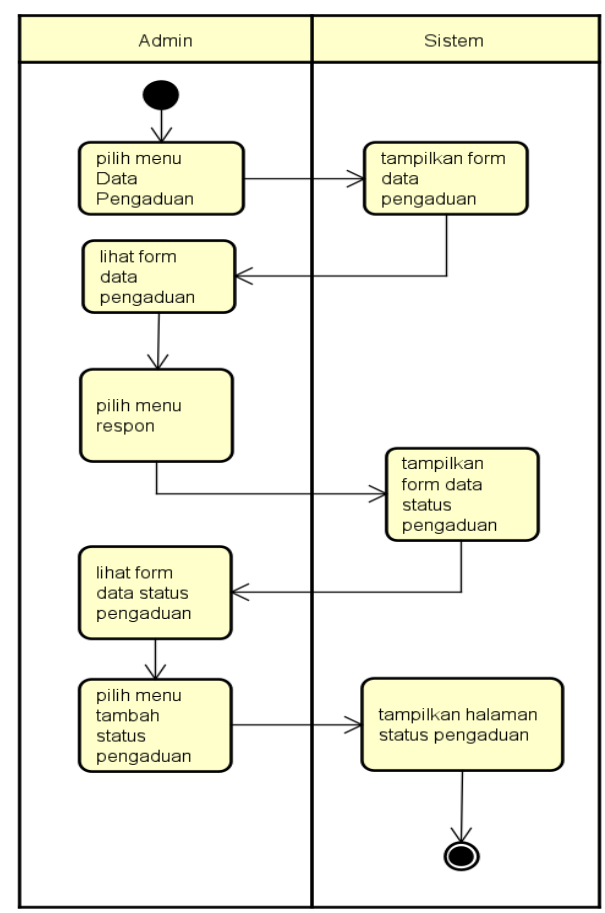

Gambar 2. Rancangan proses pengaduan
Aktifitas ini terjadi ketika admin memilih menu data pengaduan, sistem kemudian akan menampilkan form data pengaduan. Pada form data pengaduan, admin dapat memilih menu respon untuk menanggapi data pengaduan, kemudian sistem akan menampilkan halaman form data pada status pengaduan. Lalu admin dapat menambahkan status pengaduan, kemudian status pengaduan akan bertambah di dalam system dan akan ditampilkan pada halaman status pengaduan.

Rancangan aplikasi yang terdapat pada web admin dapat dilihat pada diagram usecase sebagai berikut :

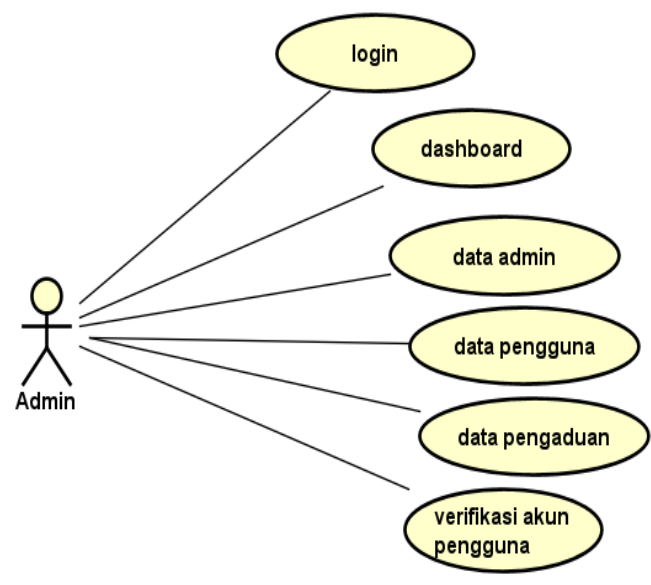

Gambar 3. Usecase rancangan Web admin

Pada rancangan aplikasi dijelaskan sistem yang akan diusulkan untuk bisa menyelesaikan masalah yang ada pada sistem berjalan. Pada usecase tersebut terdapat menu-menu yang cukup untuk memenyhi kebutuhan pelaporan masyarakat, pada umumnya menu pelaporan cukup mencakup minimal 4 fungsi yaitu : About, menu pengaduan pelanggan, menu tindak lanjut, dan menu profil [9].

Rancangan aplikasi yang terdapat pada android pengguna dapat dilihat pada gambar sebagai berikut : 


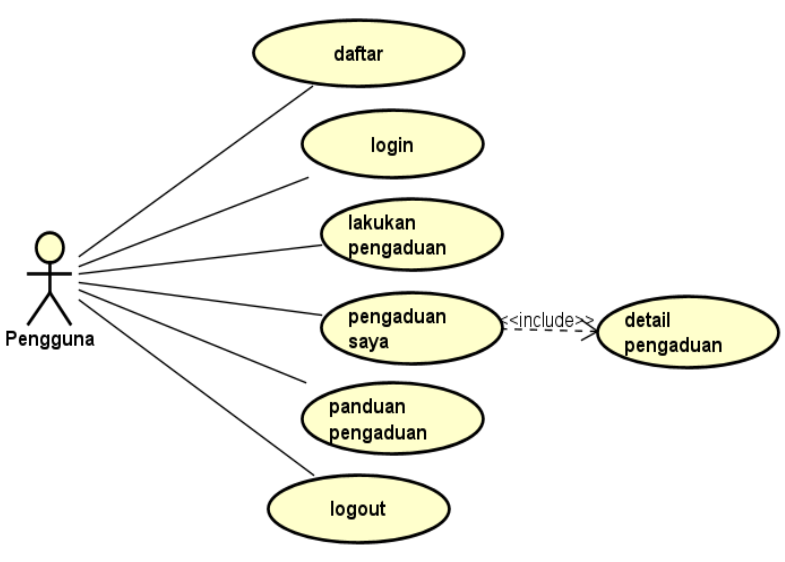

Gambar 4. Usecase rancangan pengguna android

Aplikasi android sebagai user yang dapat digunakan oleh masyarakat desa, yang nantinya dapat melakukan pengaduan masalah berdasarkan foto dan lokasi kejadian, kemudian laporan pengaduan tersebut akan masuk ke website pengaduan admin yang berperan sebagai server dan hanya bisa diakses oleh pegawai Kantor Desa yang bertugas, yang selanjutnya akan ditangani berdasarkan SOP Kantor Desa yang berlaku dan diberikan feedback kepada pengirim berita/ pelapor.[6]

Rancangan database aplikasi dapat dilihat pula dalam gambar berikut :
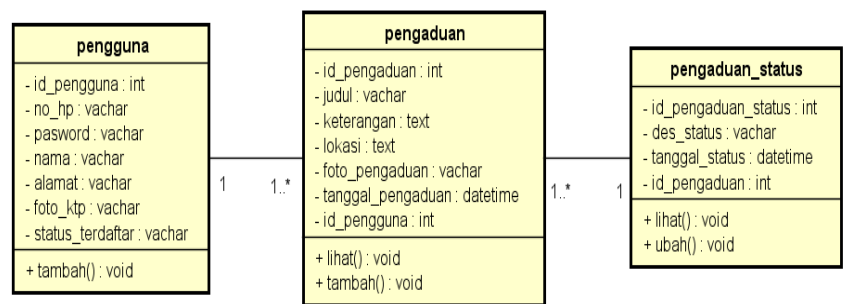

\begin{tabular}{|l|}
\hline \multicolumn{1}{|c|}{ admin } \\
\hline - id_admin: int \\
- nama: vachar \\
- username : vachar \\
- password: vachar \\
\hline +login() : void \\
+ ubah() : void \\
\hline
\end{tabular}

Gambar 5. Class diagram web admin

Dalam Class diagram tersebut dapat dilihat tabel-tabel yang dibangun untuk memenuhi kebutuhan sesuai dengan kebutuhan pengguna.

\section{E. Implementasi}

Implementasi dilapangan dilakukan berupa presentasi sistem yang akan diterapkan, sesuai dengan judul penelitian yang hanya menerapkan aplikasi prototipe saja sehinga tidak semua fitur berjalan sesuai rancangan fungsional yang ada dalam rancangan sistem. Presentasi meliputi penjelasan keseluruhan fungsi aplikasi dan teknis perawatan terhadap aplikasi.

\section{HASIL DAN PEMBAHASAN}

Hasil dari aplikasi ini merupakan sebuah aplikasi yang dharapkan mampu memenuhi jawaban atas kebutuhan pengguna dari pihak pemerintah daerah maupun masyarakat desa sebagai pengguna.

\section{A. Tampilan Web admin}

Berikut tampilan layar pada web admin :

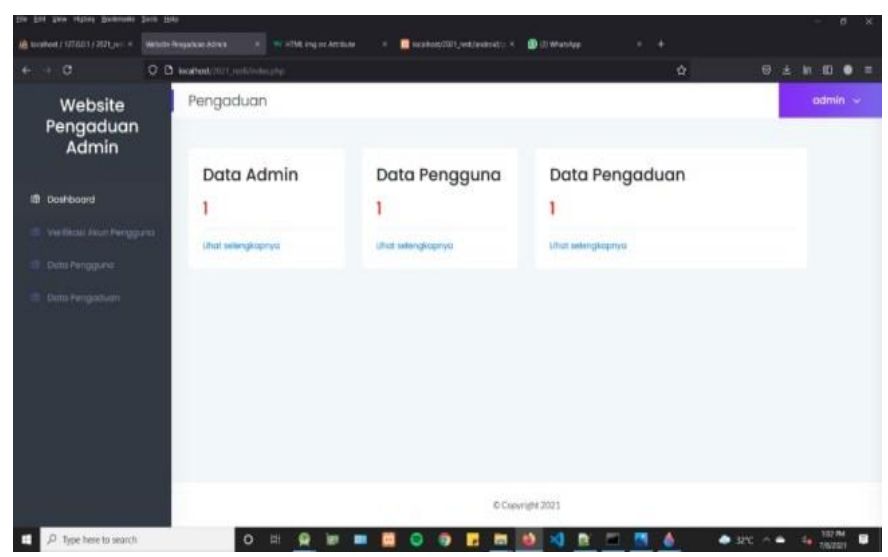

Gambar 6.Tampilan layar web admin

Gambar 6 menunjukan tampilan layar menu utama yang akan tampil ketika admin berhasil melakukan login.

\section{B. Tampilan layar Data laporan web admin}

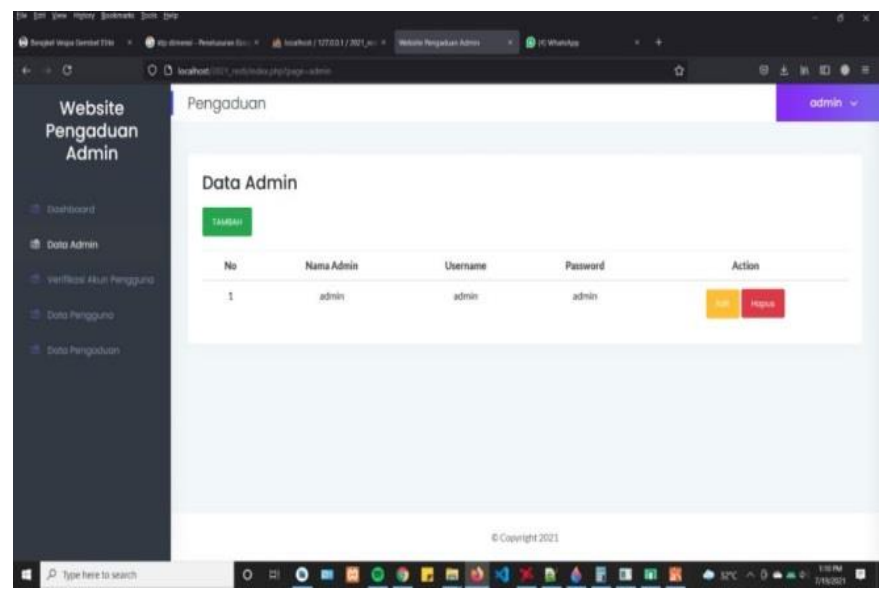

Gambar 7. Tampilan layar data web admin

Pada gambar 7 menampilkan tampilan layar data admin yang berisi data-data admin. 


\section{Tampilan layar pengaduan}

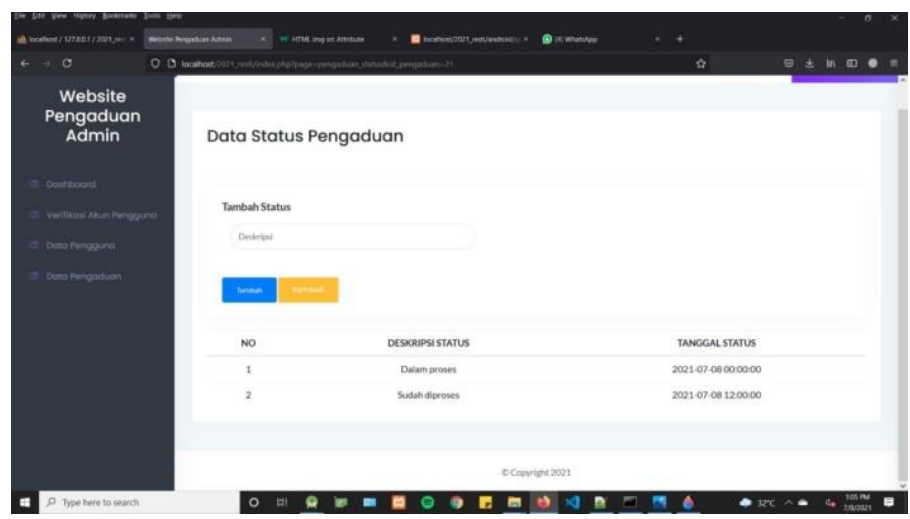

Gambar 8. Tampilan layar pengaduan

Gambar8 menunjukan tampilan awal dari layar pengaduan terhadap masyarakat.Dalam menu tersebut dapat dilihat status pengaduan apakah sudah di proses oleh pihak pemerintah desa atau belum.

\section{Tampilan layar Login pengguna}

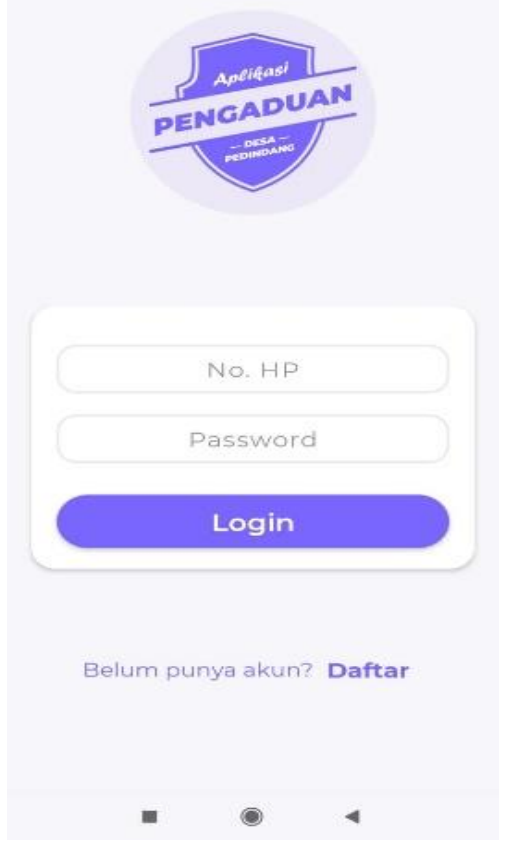

Gambar 9. Tampilan layar login pengguna

Pada gambar 9 menampilkan tampilan layar login yang akan tampil ketika aplikasi pertama kali dibuka. Disini dapat dilakukan login untuk masuk ke dalam akun pengguna.

\section{E. Tampilan layar Menu Pengguna}

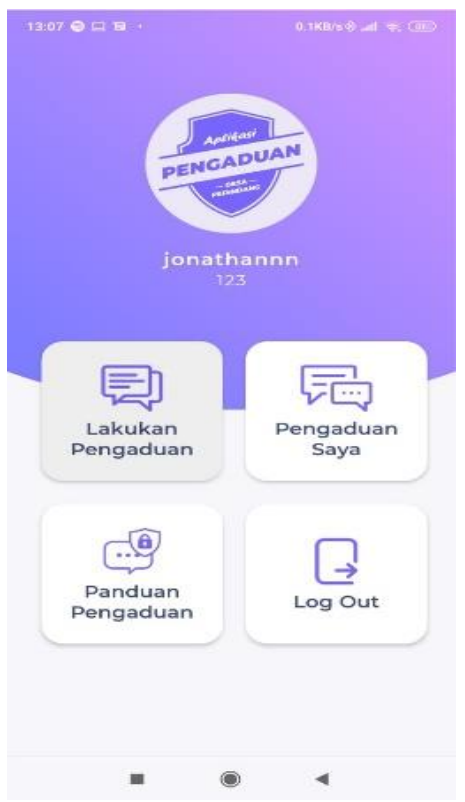

Gambar 10. Tampilan Layar Menu Utama

Pada gambar 10 menampilkan tampilan layar menu utama yang akan tampil ketika pengguna berhasil melakukan login.

\section{F. Tampilan layar Contoh proses Pengaduan}

Pada gambar 11 dibawah ini dapat dilihat contoh proses pengaduan dari masyarakat ke sistem layanan pengaduan di desa yang terdapat dalam aplikasi android pengguna .

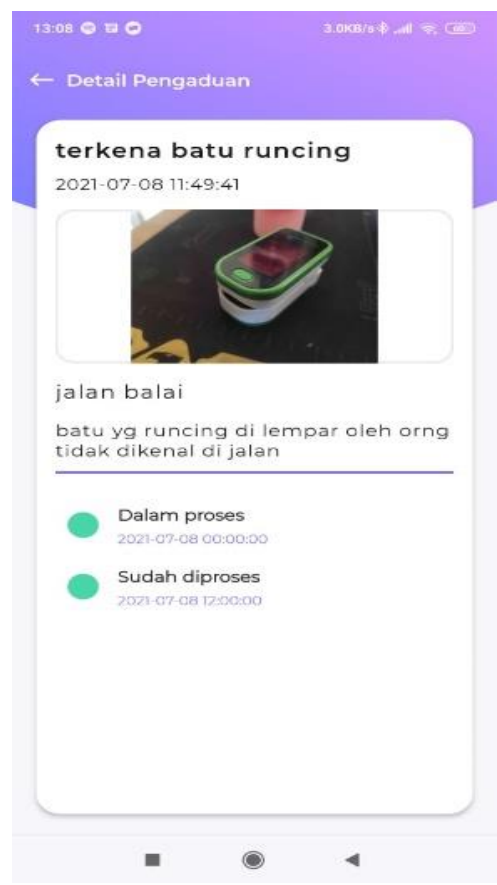

Gambar 11. Proses layanan aduan

Proses layanan aduan pada gambar11 menjelaskan detail dari isi pengaduan, dan status pengaduan yang sudah diproses atau 
belum.

\section{G. Hasil Uji Perangkat Lunak}

Tabel 3. Hasil uji perangkat lunak menggunakan model blackbox

\begin{tabular}{|c|c|c|c|c|c|}
\hline $\begin{array}{c}\text { Deskri } \\
\text { psi }\end{array}$ & $\begin{array}{c}\text { Prosed } \\
\text { ur } \\
\text { Penguj } \\
\text { ian }\end{array}$ & $\begin{array}{c}\text { Masuk } \\
\text { an }\end{array}$ & $\begin{array}{c}\text { Keluara } \\
\text { n yang } \\
\text { Diharap } \\
\text { kan }\end{array}$ & $\begin{array}{c}\text { Hasil } \\
\text { yang } \\
\text { Didapat } \\
\text { kan }\end{array}$ & $\begin{array}{c}\text { Kesimpu } \\
\text { lan }\end{array}$ \\
\hline $\begin{array}{c}\text { Admin } \\
\text { melaku } \\
\text { kan } \\
\text { login }\end{array}$ & $\begin{array}{c}\text { Admin } \\
\text { memili } \\
\text { h menu } \\
\text { login }\end{array}$ & $\begin{array}{c}\text { Admin } \\
\text { mengin } \\
\text { put ID } \\
\text { admin } \\
\& \\
\text { passwo } \\
\text { rd } \\
\text { untuk } \\
\text { melaku } \\
\text { kan } \\
\text { login }\end{array}$ & $\begin{array}{c}\text { Admin } \\
\text { berhasil } \\
\text { login }\end{array}$ & $\begin{array}{c}\text { Admin } \\
\text { berhasil } \\
\text { login dan } \\
\text { masuk ke } \\
\text { dashboar } \\
d\end{array}$ & $\begin{array}{c}\text { Apa yang } \\
\text { diinput } \\
\text { sesuai } \\
\text { yang } \\
\text { diharapka } \\
\mathrm{n}\end{array}$ \\
\hline $\begin{array}{c}\text { Admin } \\
\text { melihat } \\
\text { menu } \\
\text { data } \\
\text { admin }\end{array}$ & $\begin{array}{c}\text { Admin } \\
\text { membu } \\
\text { ka } \\
\text { menu } \\
\text { tersebu } \\
\text { t untuk } \\
\text { melihat } \\
\text { data } \\
\text { admin }\end{array}$ & $\begin{array}{c}\text { Admin } \\
\text { membu } \\
\text { ka data } \\
\text { admin } \\
\text { yang } \\
\text { tersimp } \\
\text { an } \\
\text { dalam } \\
\text { databa } \\
\text { se }\end{array}$ & $\begin{array}{c}\text { Data } \\
\text { admin } \\
\text { tersimpan } \\
\text { di } \\
\text { database }\end{array}$ & $\begin{array}{c}\text { Data } \\
\text { admin } \\
\text { berhasil } \\
\text { di edit } \\
\text { dan } \\
\text { tersimpan } \\
\text { di } \\
\text { database }\end{array}$ & $\begin{array}{c}\text { Apa yang } \\
\text { diinput } \\
\text { sesuai } \\
\text { yang } \\
\text { diharapka } \\
\text { n }\end{array}$ \\
\hline $\begin{array}{c}\text { Admin } \\
\text { melihat } \\
\text { menu } \\
\text { data } \\
\text { penggu } \\
\text { na }\end{array}$ & $\begin{array}{c}\text { Admin } \\
\text { membu } \\
\text { ka } \\
\text { menu } \\
\text { tersebu } \\
\text { t untuk } \\
\text { melihat } \\
\text { data } \\
\text { penggu } \\
\text { na }\end{array}$ & $\begin{array}{c}\text { Admin } \\
\text { membu } \\
\text { ka } \\
\text { hasil } \\
\text { masuka } \\
\text { n dari } \\
\text { user }\end{array}$ & $\begin{array}{c}\text { Data } \\
\text { pengguna } \\
\text { tersimpan } \\
\text { dalam } \\
\text { database }\end{array}$ & $\begin{array}{c}\text { Data } \\
\text { pengguna } \\
\text { sudah } \\
\text { tersimpan } \\
\text { dalam } \\
\text { database }\end{array}$ & $\begin{array}{c}\text { Apa yang } \\
\text { diinput } \\
\text { sesuai } \\
\text { yang } \\
\text { diharapka } \\
n\end{array}$ \\
\hline $\begin{array}{c}\text { Admin } \\
\text { melihat } \\
\text { menu } \\
\text { data } \\
\text { pengad } \\
\text { uan }\end{array}$ & $\begin{array}{c}\text { Admin } \\
\text { membu } \\
\text { ka } \\
\text { menu } \\
\text { tersebu } \\
\text { t untuk } \\
\text { melihat } \\
\text { data } \\
\text { pengad } \\
\text { uan }\end{array}$ & $\begin{array}{c}\text { Admin } \\
\text { membu } \\
\text { ka } \\
\text { hasil } \\
\text { masuka } \\
\text { n dari } \\
\text { user }\end{array}$ & $\begin{array}{c}\text { Data } \\
\text { pengadua } \\
\mathrm{n} \\
\text { tersimpan } \\
\text { dalam } \\
\text { database }\end{array}$ & $\begin{array}{c}\text { Data } \\
\text { pengadua } \\
\mathrm{n} \text { sudah } \\
\text { tersimpan } \\
\text { dalam } \\
\text { database }\end{array}$ & $\begin{array}{c}\text { Apa yang } \\
\text { diinput } \\
\text { sesuai } \\
\text { yang } \\
\text { diharapka } \\
n\end{array}$ \\
\hline $\begin{array}{c}\text { Admin } \\
\text { melihat } \\
\text { menu } \\
\text { verifik } \\
\text { asi } \\
\text { akun } \\
\text { penggu } \\
\text { na }\end{array}$ & $\begin{array}{c}\text { Admin } \\
\text { membu } \\
\text { ka } \\
\text { menu } \\
\text { tersebu } \\
\text { t untuk } \\
\text { melihat } \\
\text { data } \\
\text { verifik } \\
\text { asi } \\
\text { akun } \\
\text { penggu } \\
\text { na }\end{array}$ & $\begin{array}{c}\text { Admin } \\
\text { membu } \\
\text { ka } \\
\text { hasil } \\
\text { masuka } \\
\text { n dari } \\
\text { user }\end{array}$ & $\begin{array}{c}\text { Data } \\
\text { verifikasi } \\
\text { akun } \\
\text { pengguna } \\
\text { tersimpan } \\
\text { dalam } \\
\text { database }\end{array}$ & $\begin{array}{c}\text { Data } \\
\text { verifikasi } \\
\text { akun } \\
\text { pengguna } \\
\text { sudah } \\
\text { tersimpan } \\
\text { dalam } \\
\text { database }\end{array}$ & $\begin{array}{c}\text { Apa yang } \\
\text { diinput } \\
\text { sesuai } \\
\text { yang } \\
\text { diharapka } \\
n\end{array}$ \\
\hline $\begin{array}{c}\text { Penggu } \\
\text { na } \\
\text { melaku } \\
\text { kan } \\
\text { daftar } \\
\text { akun }\end{array}$ & $\begin{array}{c}\text { Penggu } \\
\text { na } \\
\text { memili } \\
\text { h menu } \\
\text { daftar }\end{array}$ & $\begin{array}{c}\text { Penggu } \\
\text { na } \\
\text { mengin } \\
\text { put } \\
\text { data- } \\
\text { data }\end{array}$ & $\begin{array}{c}\text { Akun } \\
\text { pengguna } \\
\text { tersimpan } \\
\text { dalam } \\
\text { database }\end{array}$ & $\begin{array}{c}\text { Akun } \\
\text { pengguna } \\
\text { sudah } \\
\text { tersimpan } \\
\text { dalam } \\
\text { database }\end{array}$ & $\begin{array}{c}\text { Apa yang } \\
\text { diinput } \\
\text { sesuai } \\
\text { yang } \\
\text { diharapka } \\
\text { n }\end{array}$ \\
\hline
\end{tabular}

\begin{tabular}{|c|c|c|c|c|c|}
\hline $\begin{array}{c}\text { Deskri } \\
\text { psi }\end{array}$ & $\begin{array}{c}\text { Prosed } \\
\text { ur } \\
\text { Penguj } \\
\text { ian }\end{array}$ & $\begin{array}{c}\text { Masuk } \\
\text { an }\end{array}$ & $\begin{array}{c}\text { Keluara } \\
\text { n yang } \\
\text { Diharap } \\
\text { kan }\end{array}$ & $\begin{array}{c}\text { Hasil } \\
\text { yang } \\
\text { Didapat } \\
\text { kan }\end{array}$ & $\begin{array}{c}\text { Kesimpu } \\
\text { lan }\end{array}$ \\
\hline & & $\begin{array}{c}\text { untuk } \\
\text { melaku } \\
\text { kan } \\
\text { daftar }\end{array}$ & & & \\
\hline $\begin{array}{c}\text { Penggu } \\
\text { na } \\
\text { melaku } \\
\text { kan } \\
\text { login }\end{array}$ & $\begin{array}{c}\text { Penggu } \\
\text { na } \\
\text { memili } \\
\mathrm{h} \text { menu } \\
\text { login }\end{array}$ & $\begin{array}{c}\text { Penggu } \\
\text { na } \\
\text { mengin } \\
\text { put no } \\
\text { hp \& } \\
\text { passwo } \\
\text { rd } \\
\text { untuk } \\
\text { melaku } \\
\text { kan } \\
\text { login }\end{array}$ & $\begin{array}{c}\text { Pengguna } \\
\text { berhasil } \\
\text { login }\end{array}$ & $\begin{array}{c}\text { Pengguna } \\
\text { berhasil } \\
\text { login dan } \\
\text { masuk ke } \\
\text { menu } \\
\text { utama }\end{array}$ & $\begin{array}{c}\text { Apa yang } \\
\text { diinput } \\
\text { sesuai } \\
\text { yang } \\
\text { diharapka } \\
\text { n }\end{array}$ \\
\hline $\begin{array}{c}\text { Penggu } \\
\text { na } \\
\text { melihat } \\
\text { menu } \\
\text { lakuka } \\
n \\
\text { pengad } \\
\text { uan }\end{array}$ & $\begin{array}{c}\text { Penggu } \\
\text { na } \\
\text { membu } \\
\text { ka } \\
\text { menu } \\
\text { tersebu } \\
\text { t untuk } \\
\text { melaku } \\
\text { kan } \\
\text { pengad } \\
\text { uan }\end{array}$ & $\begin{array}{c}\text { Penggu } \\
\text { na } \\
\text { mengis } \\
\text { i data } \\
\text { untuk } \\
\text { melaku } \\
\text { kan } \\
\text { pengad } \\
\text { uan }\end{array}$ & $\begin{array}{c}\text { Pengadua } \\
\text { n } \\
\text { tersimpan } \\
\text { ke dalam } \\
\text { database }\end{array}$ & $\begin{array}{l}\text { Pengadua } \\
\text { n berhasil } \\
\text { tersimpan } \\
\text { ke dalam } \\
\text { database }\end{array}$ & $\begin{array}{c}\text { Apa yang } \\
\text { diinput } \\
\text { sesuai } \\
\text { yang } \\
\text { diharapka } \\
\text { n }\end{array}$ \\
\hline $\begin{array}{c}\text { Penggu } \\
\text { na } \\
\text { melihat } \\
\text { menu } \\
\text { pandua } \\
n \\
\text { pengad } \\
\text { uan }\end{array}$ & $\begin{array}{c}\text { Penggu } \\
\text { na } \\
\text { membu } \\
\text { ka } \\
\text { menu } \\
\text { tersebu } \\
\text { t untuk } \\
\text { melihat } \\
\text { pandua } \\
\text { n } \\
\text { pengad } \\
\text { uan } \\
\end{array}$ & $\begin{array}{c}\text { Penggu } \\
\text { na } \\
\text { melihat } \\
\text { masuka } \\
\text { n dari } \\
\text { databa } \\
\text { se }\end{array}$ & $\begin{array}{c}\text { Pengguna } \\
\text { melihat } \\
\text { panduan } \\
\text { pengadua } \\
\text { n dari } \\
\text { database }\end{array}$ & $\begin{array}{c}\text { Pengguna } \\
\text { berhasil } \\
\text { melihat } \\
\text { panduan } \\
\text { pengadua } \\
\text { n dari } \\
\text { database }\end{array}$ & $\begin{array}{c}\text { Apa yang } \\
\text { diinput } \\
\text { sesuai } \\
\text { yang } \\
\text { diharapka } \\
\text { n }\end{array}$ \\
\hline $\begin{array}{c}\text { Penggu } \\
\text { na } \\
\text { melihat } \\
\text { menu } \\
\text { pengad } \\
\text { uan } \\
\text { saya }\end{array}$ & $\begin{array}{c}\text { Penggu } \\
\text { na } \\
\text { membu } \\
\text { ka } \\
\text { menu } \\
\text { tersebu } \\
\text { t untuk } \\
\text { melihat } \\
\text { daftar } \\
\text { pengad } \\
\text { uan } \\
\text { saya }\end{array}$ & $\begin{array}{c}\text { Penggu } \\
\text { na } \\
\text { memili } \\
\text { h } \\
\text { daftar } \\
\text { pengad } \\
\text { uan }\end{array}$ & $\begin{array}{c}\text { Pengguna } \\
\text { melihat } \\
\text { detail } \\
\text { pengadua } \\
\text { n dari } \\
\text { database }\end{array}$ & $\begin{array}{c}\text { Pengguna } \\
\text { berhasil } \\
\text { melihat } \\
\text { detail } \\
\text { pengadua } \\
\text { n dari } \\
\text { database }\end{array}$ & $\begin{array}{c}\text { Apa yang } \\
\text { diinput } \\
\text { sesuai } \\
\text { yang } \\
\text { diharapka } \\
\text { n }\end{array}$ \\
\hline
\end{tabular}

Tabel 3 diatas adalah hasil pengujian perangkat lunak dari sisi admin dan pengguna menggunakan metode blackbox.

\section{PENUTUP}

\section{A. Kesimpulan}

Berdasarkan hasil penelitian yang dilakukan oleh peneliti dapat disimpulkan beberapa kesimpulan setelah melakukan pengerjaan aplikasi layanan pengaduan masyarakat di kantor desa berbasis Android adalah sebagai berikut :

1. Bahwa merancang aplikasi layanan pengaduan berbasis Android dibutuhkan peran serta masyarakat dan pihak pemerintah desa untuk membantu proses pengembangan.

\section{p-ISSN 2301-7988, e-ISSN 2581-0588}

DOI : 10.32736/sisfokom.v10i3.1295, Copyright @ 2020 
2. Dengan sistem pengaduan yang telah dibuat dapat memudahkan masyarakat dalam menggunakan haknya sebagai masyarakat desa untuk membuat aduan tentang kondisi terkini desa mereka.

3. Dengan aplikasi ini terciptalah sebuah sistem yang bisa mengelola, mendokumentasikan dan memproses layanan terhadap pengaduan atau keluhan dari masyarakat.

4. Dari tabel2 terdapat hasil kuesioner dan dapat di lihat bahwa 8 orang responden dari pihak pemerintahan desa menyatakan setuju dengan diperlukannya aplikasi ini bagi kebutuhan masyarakat desa dan pemerintahan desa. Sementara itu dari pihak masyarakat 10 orang menyatakan sangat setuju dengan dibuatnya aplikasi ini, 20 orang menyatakan setuju dan ada 2 orang menyatakan tidak setuju dengan diterapkannya aplikasi ini.

5. Dari tabel dibawah ini dapat dilihat tingkat kepuasan pemakai terhadap aplikasi ini

Tabel 4. Survey Kepuasan terhadap aplikasi

\begin{tabular}{|c|c|c|c|c|c|}
\hline \multirow[t]{2}{*}{ No } & \multirow[t]{2}{*}{ Pernyataan } & \multicolumn{4}{|c|}{ Penilaiaan } \\
\hline & & SS & $\mathrm{S}$ & TS & STS \\
\hline 1 & $\begin{array}{l}\text { Apakah aplikasi yang } \\
\text { digunakan mampu memenuhi } \\
\text { fungsinya? }\end{array}$ & 10 & 30 & 0 & 0 \\
\hline 2 & $\begin{array}{l}\text { Apakah aplikasi mudah } \\
\text { digunakan? }\end{array}$ & 10 & 30 & 0 & 0 \\
\hline 3 & $\begin{array}{l}\text { Apakah aplikasi dapat } \\
\text { memudahkan petugas dalam } \\
\text { pelayanan? } *\end{array}$ & 6 & 2 & 0 & 0 \\
\hline 4 & $\begin{array}{l}\text { Apakah proses tanggapan } \\
\text { laporan mudah dilakukan? } *\end{array}$ & 6 & 2 & 0 & 0 \\
\hline 5 & $\begin{array}{l}\text { Apakah aplikasi merupakan } \\
\text { layanan baru dalam } \\
\text { masyarkat? }\end{array}$ & 35 & 5 & 0 & 0 \\
\hline 6 & $\begin{array}{l}\text { Apakah aplikasi tidak } \\
\text { membutuhkan spesifikasi } \\
\text { gadget yang tinggi? }\end{array}$ & 12 & 25 & 3 & 0 \\
\hline 7 & $\begin{array}{l}\text { Apakah aplikasi memenuhi } \\
\text { imformasi terbaru bagi } \\
\text { masyarkat desa? }\end{array}$ & 0 & 5 & 25 & 10 \\
\hline 8 & $\begin{array}{l}\text { Apakah penggunaan aplikasi } \\
\text { ini membingungkan? }\end{array}$ & 0 & 5 & 15 & 20 \\
\hline 9 & $\begin{array}{l}\text { Apakah aplikasi ini snagat } \\
\text { bermanfaat? }\end{array}$ & 38 & 2 & 0 & 0 \\
\hline & $\begin{array}{c}\text { Ianya dijawab oleh perangkat } \\
\text { desa }\end{array}$ & & & & \\
\hline
\end{tabular}

Pada tabel 4 diatas dapat dilihat kepuasan terhadap aplikasi layanan sangat layak untuk dilakukan untuk mengetahui sejauh mana masyarakat memberikan apresiasi dan tingkat antusiasme masyarakat terhadap layanan tersebut [10].

\section{B. Saran}

Berdasarkan penelitian ini yaitu sebuah rancangan prototype perangkat sistem aplikasi layanan pengaduan masyarakat di kantor Desa berbasis Android, berikut dibawah ini diharapkan dapat menjadi bahan pertimbangan untuk peneliti atau pengembangan sistem selanjutnya yang agar penelitian dan pengembangan aplikasi layanan aduan yang menggunakan desa ini diharapkan mampu menjadi pilot project sebagai acuan bagi seluruh desa di kepulauan Bangka belitung untuk dapat menerapkan layanan pengaduan masyarakat desa untuk diterapkan oleh pemerintah daerah.

\section{DAFTAR PUSTAKA}

[1] Galih Nalendro. 2019. Sistem informasi pengaduan layanan Universitas. [Skripsi]. Yogyakarta (ID): Universitas Islam Indonesia.

[2] R. H. Dai., "(ELINVO) Electronic, Informatics, and Vocational Education," Rancang Bangun Aplikasi E-Report Pengaduan Masyarakat Design Public Complaint E-Report Aplication, vol 2, no 1, pp 3-10, Mei 2017

[3] Jurman Bin Jamaluddin. 2020. Inovasi Pelayanan Pengaduanwarga Berbasis Online Di Desa Pakto Kabupaten Gowa. [Skripsi]. Makassar (ID): Universitas Muhammadiyah Makassar.

[4] S. W. Mursalim, "Media pengembangan ilmu dan praktek Administrasi," Analisis manajemen pengaduan sistem layanan aspirasi pengaduan online rakyat (LAPOR) di Kota Bandung, vol.xv, no. 1, pp 1-17, Juni 2018.

[5] Mazdalifah. 2018. Perancangan aplikasi pengaduan masyarakat di Kecamatan Secanggang menggunakan Android. [Skripsi]. Medan (ID): Universitas Sumatera Utara.

[6] Ahmad Jauharul Aknana. 2020. Peran pelayanan publik dalam penanganan pengaduan masyarakat [Skripsi]. Tulungagung (ID): Institut Agama Islam Negeri Tulungagung.

[7] Andi Maryam Ulfa.2017. Responsivitas pelayanan publik. (Studi Kasus : Pelayanan Polres Enrekang Terhadap Pengaduan Masyarakat). Makassar (ID): Universitas Hasanuddin.

[8] Maya Sofianti. 2020. Responsivitas pelayanan pengaduan masyarakat di kantor Kepolisian Sektor Alla Kabupaten Enrekang. [Skripsi]. Makassar (ID): Universitas Muhammadiyah Makassar.

[9] Fadhilah Fatin. 2017. Aplikasi pengaduan pelanggan berbasis Android di pdam tirta satria Kabupaten Banyumas. [Skripsi]. Semarang (ID): Universitas Negeri Semarang.

[10] Dandhi Dwirizky Purwiansyah. 2020. Implementasi Uu No. 25 Tahun 2009 Tentang Pelayanan Publik (Studi Penyediaan Layanan Pengaduan Masyarakat Berbasis Online Di Kabupaten Tegal. [Skripsi]. Tegal (ID): Universitas Pancasakti Tegal.

[11] Indrawati. (2020). Penanganan Laporan Pengaduan Masyarakat Tehadap Proses Penyidikan Polri Di Tingkat Polres Dan Polsek Kota Malang. Volume (1), No.1, halaman 40-50. 